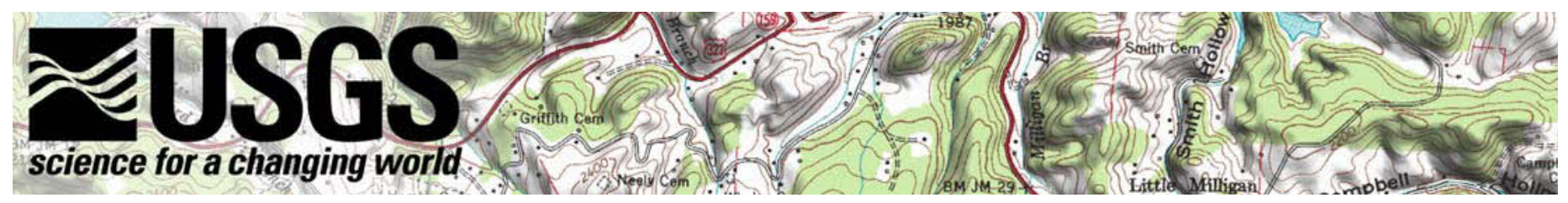

\title{
Cooperative Topographic Mapping Program
}

The mission of the Cooperative Topographic Mapping (CTM) Program of the U.S. Geological Survey (USGS) is to provide the Nation with access to current, accurate, and consistent base geographic data and derivative products, including topographic maps. The CTM Program has the lead responsibility to develop, maintain, and make available The National Map.

\section{The Nation Needs The National Map}

Governments depend on a common set of base geographic information as a tool for economic and community development, land and natural resource management, scientific investigation, and health and safety services. Emergency management and homeland security applications rely on this information. Private industry, nongovernmental organizations, and individual citizens use the same geographic data. Geographic information underpins an increasingly large part of the Nation's economy.

Available geographic data often have the following problems:

Do not align with each other because layers are frequently created or revised separately,

Do not match across administrative boundaries because each producing organization uses different methods and standards, and

Are not up to date because of the complexity and cost of revision.

The USGS is developing The National Map to be a seamless, continuously maintained, and nationally consistent set of online, public domain, geographic base information to resolve these issues. The National Map will serve as a foundation for integrating, sharing, and using other data easily and consistently. In collaboration with other Federal, State, county, and local government agencies, the private sector, academia, and the public, the USGS will coordinate, integrate, and, where needed, produce and maintain base geographic data.

The National Map will include digital orthorectified imagery, elevation data, vector data for hydrography, transportation, boundary, and structure features, geographic names, and land cover information. The data will be the source of revised paper topographic maps.

\section{CTM Program Goals}

The USGS traditionally has produced base geographic information and has made that information available as topographic quadrangle maps and digital products, such as line graphs, elevation models, and raster graphics. The CTM Program 5-Year Plan calls for a dramatic realignment of USGS roles to deemphasize data production in order to focus on partnerships for data sharing. State and local governments and the private sector conduct mapping operations that provide much of the data content required for The National Map. Integrating these data into a distributed set of public domain, nationally consistent information and making those data immediately accessible over the Web are the keys to achieving the goals of The National Map.

The CTM Program 5-Year Plan documents the major objectives of the program:

- Assemble and maintain a seamless, continuously maintained, nationally consistent set of public domain, base geographic data.
- Establish and sustain partnerships for data collection, integration, updating, and dissemination.

- Derive updated topographic maps from the base geographic data.

- Promote the adoption of The National Map as the geographic underpinning for other Federal mapping activities and those of other public and private organizations.

\section{Implementation}

Ensuring the availability of current and complete base geographic data for the Nation requires innovative approaches to coordinating mapping and related activities. The CTM Program promotes activities that focus on achieving the full characteristics of The National Map. The following are examples of these activities.

Mapping Partnership Offices. The USGS workforce will emphasize partnership development, data integration, information management, and geographic applications. By placing an increasing fraction of its workforce in offices that are collocated with other USGS discipline staff or with Federal and State partner agencies, the USGS will provide resources and expertise that will encourage and sustain cooperative activities that emphasize data sharing and distributed data stewardship. In Austin, Texas, the USGS Mapping Partnership Office shares office space with USGS Water Resources Discipline staff and supports a partnership with the Texas Natural Resource Information System StratMap to implement The National Map (tnris.state.tx.us/stratmap/).

State Partnerships. State-level consortia that bring together State, county, and local mapping activities are 
important for accomplishing The

National Map. Many partnerships are

being created. Delaware authorities are working closely with the USGS to provide Web access to seamless Federal, State, county, and local base geographic data (www.datamil.udel.edu/ nationalmappilot/).

Federal Partnerships. Many Federal agencies collect base geographic data. By sharing and maintaining these data through long-term partnerships, the USGS is implementing the principles of the National Spatial Data Infrastructure and the Office of Management and Budget's Geospatial One-Stop Initiative for geographic data access. For example, the USGS is developing a partnership

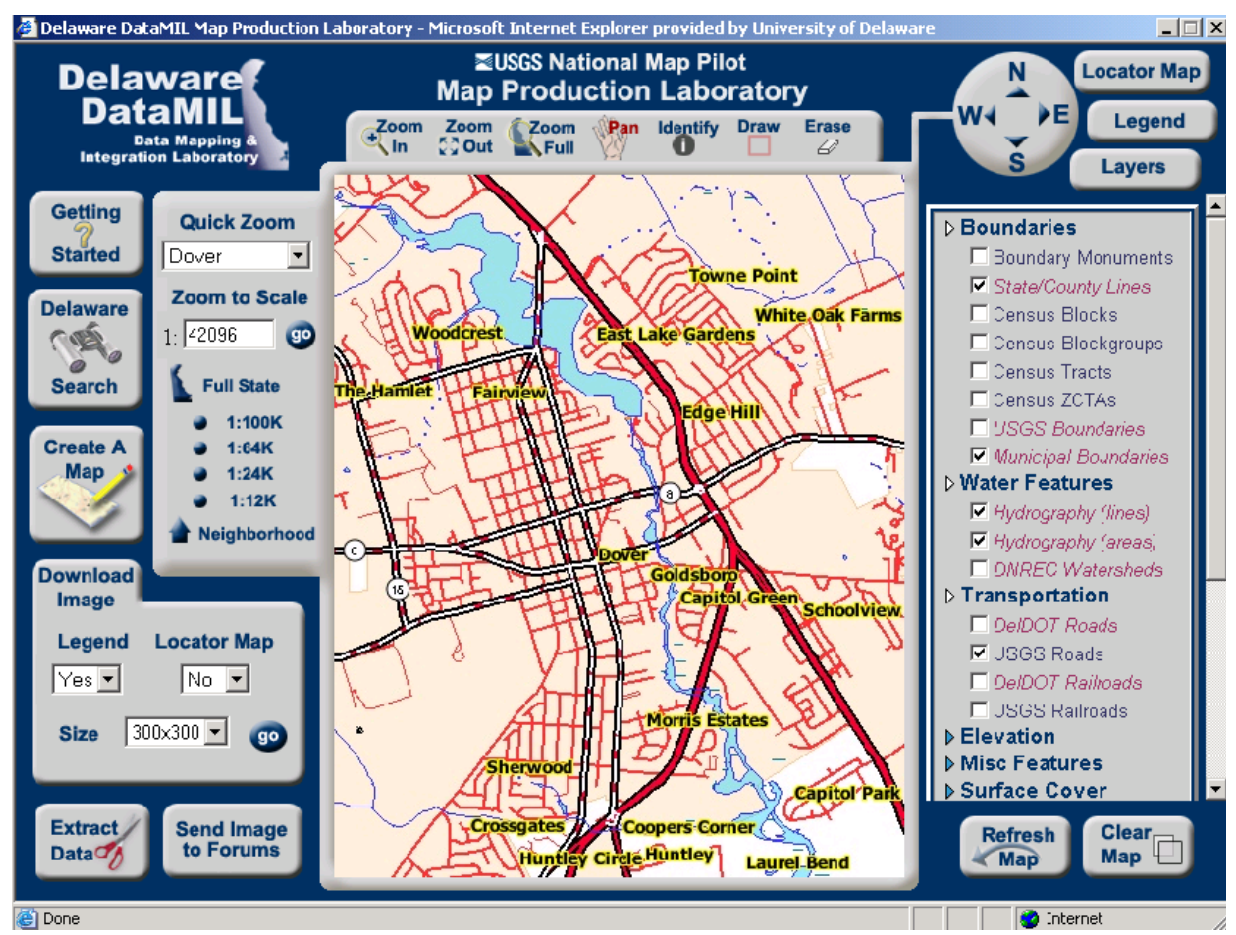

The CTM 5-Year Plan promotes partnerships that provide for data sharing, maintenance, and dissemination. The Delaware DataMIL Web site provides data access, visualization, mapping, and discussion capabilities.

with the Bureau of the Census to incorporate updated transportation and boundary data, compiled as part of the update of the TIGER database, into The National Map.

Volunteers. Knowing about changes on the landscape is critical to maintaining data currentness. A major source for update information may be volunteers. The current mapping volunteer program, the Earth Science Corps, will be the base for new approaches that take advantage of emerging technologies, such as personal digital assistant devices and wireless Web access, to obtain feature status and change information from volunteers.

Homeland Security. In partnership with the National Imagery and Mapping Agency, the USGS provides base geographic data to meet homeland security needs and to populate The National Map. Current emphasis on major cities focuses on obtaining highresolution aerial imagery and additional information about critical infrastructure from local government and commercial sources.

Data Access. Web access to the data of The National Map and Web-based mapping tools that provide data visualization and mapping functionality these maps, providing validated base geographic data that are the foundation for the initial implementation of The National Map and for future partnerships that will provide for long-term data maintenance.

\section{Partnership Opportunities}

Government agencies, private sector companies, professional organizations, nongovernment organizations, and others interested in partnering with the CTM Program to develop, maintain, provide, and apply geographic information in the context of The National Map should contact the USGS mapping liaison in their State. The list of liaisons is available at mapping.usgs.gov/ index.html\#partners. Click on "Mapping Partnership Programs."

\section{Information}

Further information about The National Map and the CTM Program and its component activities is available from the Cooperative Topographic Mapping Program, Mail Stop 511, USGS National Center, 12201 Sunrise Valley Drive, Reston, VA 20192.

You can view and download the CTM Program 5-Year Plan and more information about The National Map vision and its principal components at nationalmap.usgs.gov.

For information on other USGS products and services, call 1-888-ASK-USGS or visit the general interest publications Web site on mapping, geography, and related topics at mac.usgs.gov/mac/isb/ pubs/pubslists/.

For additional information, visit the ask.usgs.gov Web site or the USGS home page at www.usgs.gov. are essential to making geographic knowledge available. The CTM Program supports a Web portal that will be a single access point to The National Map. Users will be able to define a geographic area of interest, browse metadata for available data, select content that meets their unique needs, and display and print maps from these data.

Large Block Revision. Significant rural and less-developed areas are covered by topographic maps that were last revised years ago but that may still be current since little landscape change occurs in such areas. The CTM Program funds photoinspection and limited updates of 